\title{
CULTURA CINEMATOGRÁFICA Y NARRATIVA NOIR EN LA OBRA DE RAYMOND CHANDLER
}

\author{
José ISMAel GutiérRez \\ Universidad de Las Palmas de Gran Canaria
}

\section{Resumen}

Cine y literatura se fusionan eventualmente en la obra de Raymond Chandler. Esta simbiosis se realiza tanto en el plano ficcional como en el nivel puramente discursivo. Es este último aspecto el que se analiza en este artículo. A través de figuras retóricas como la comparación, la hipotiposis y determinadas técnicas que sugieren un encuadre cinematográfico o los movimientos de una cámara, la narrativa del escritor norteamericano entabla un diálogo interdiscursivo con un arte de masas que forma parte ya de la cultura contemporánea.

Palabras clave: Chandler, narrativa negra, cine, literatura.

\section{CINEMATOGRAPHIC CULTURE AND NOIR NARRATIVE IN RAYMOND CHANDLER'S WORK}

\begin{abstract}
Film and literature are occasionally merged into the work of Raymond Chandler. This symbiosis is performed both on the fictional level and on the purely discursive level. It is this last aspect that is analyzed in this article. By using rhetorical figures such as comparison, hypotyposis and certain techniques that suggest a cinematographic framing or the movements of a camera, the narrative of this American writer engages in an interdiscursive dialogue with a mass art that is already part of contemporary culture.

Keywords: Chandler, noir narrative, cinema, literature.
\end{abstract}




\section{INTRODUCGIÓN}

Las interacciones entre cine y literatura se pueden enfocar desde diversos ángulos complementarios. Juan Manuel de Prada (2006: 15) señala dos:

El primero se conforma con estudiar la influencia de la literatura en el cine, bien mediante la participación directa del escritor en la elaboración del guion, bien mediante la adaptación del cine de una obra literaria. El otro punto de vista, más complejo y subliminar, atañe a la cada vez más pujante influencia del cine, de la narración cinematográfica, en la narración escrita.

Una tercera vía se acoge a una perspectiva intermedia que rehúsa privilegiar alguna de las dos formas de expresión artística y comunicacional implicadas para adoptar un enfoque comparatista desprovisto de cualquier intención jerarquizada. Así, el semiólogo Jost (2002), en su análisis del relato cinematográfico, lejos de seguir los planteamientos tradicionales con los que se abordaba la relación entre cine y literatura, basada en un deslizamiento unidireccional de las conquistas del primero en la segunda, o viceversa, opta por una actitud vacilante en la que ambos dominios se entrecruzan pero sin llegar a confundirse.

Sin ánimo de desatender otras vertientes del problema, se puede afirmar que es en el plano discursivo donde con mayor facilidad se disciernen las analogías entre la producción fílmica y la literatura. La injerencia de técnicas temporalizadoras o la yuxtaposición y exhibición de argumentos diegéticos ficcionales en el espacio escriturado del relato de acuerdo con unas estrategias que, por su ordenación y dinamismo, recuerdan la fórmula del montaje cinematográfico, por solo citar un ejemplo, dan la talla de estas concomitancias. En ocasiones será el modo de «pintar» a personajes, acciones o atmósferas — naturales o artificiales, interiores o exteriores- con arreglo a procedimientos como el simultaneísmo u otros que acentúan la plasticidad $\mathrm{y}$ visualidad de las descripciones lo que decida el alcance de tales alianzas.

Debatidas por diferentes autores y escuelas de la teoría literaria y filmográfica, dichas zonas de convergencia (o, para algunos, evidentes contagios) empiezan a explorarse en la praxis de la escritura narrativa durante la época de las vanguardias históricas y, en especial, gracias a la labor de los grandes renovadores de la novela del siglo pasado, todos los cuales asisten al nacimiento y consolidación del séptimo arte cuyos aportes, de un modo u otro, repercutirán tanto en sus vidas como en sus creaciones. El escritor norteamericano John Dos Passos, uno de los miembros de la «generación perdida», evocó en 1967 que por los años en que escribió Manhattan Transfer (1925) se sentía tan impresionado por el montaje de las secuencias de The Birth of a Nation (1915), de D.W. Griffith, que intentó reproducir un efecto parecido valiéndose de ese dispositivo. En esta misma entrevista concedida 
al editor de The Paris Review confesaba no acordarse de si ya por entonces había visto alguna película de otro director de culto que revolucionó el lenguaje del cine con su peculiar forma de enlazar impactantes escenas colectivas a fin de transmitir emociones y mensajes con los que adoctrinar al espectador del recién estrenado régimen comunista: el ruso Sergei Eisenstein (Plimpton, 1976: 80) ${ }^{1}$.

Ahora bien, a la hora de determinar qué fue primero, si el legado cinematográfico o el soporte narratológico de carácter literario que lo respalda y qué elemento se aprovechó primero del otro, no parece haber consenso. Estudiosos y creadores contemporáneos han reparado en la existencia de significantes «fílmicos» en obras de la literatura muy anteriores a la misma invención del celuloide: la Odisea de Homero, La vida es sueño de Calderón o el teatro de Zola son algunos de los referentes a los que se suele acudir para defender esta hipótesis (cf. Vázquez Abeijón, 2017: 32)², llegándose a sugerir incluso que algunos cineastas se inspiraron, para confeccionar sus películas, en modelos constructivos que tomaron prestados de ciertas piezas literarias. Así, en el ensayo «Dickens, Griffith y el cine en la actualidad», redactado en 1944 por un Eisenstein retornado a la Unión Soviética, se apunta a Dickens y a su empleo de la alternancia de una doble historia como antepasado del cinematógrafo y se suscribe que, mucho antes que el director estadounidense, el escritor victoriano había inventado la técnica del montaje narrativo, que, al fin y al cabo, depende de una acción paralela (Eisenstein, 1995: 190).

Finalmente, otra variable axiomática especula con la tesis de que probablemente se trate de similitudes fortuitas, es decir, que cada arte habría de desarrollar esos recursos por su cuenta, aunque, llegado un momento difícil de concretar, convergerían en un tramo del proceso creativo, reforzándose así los nexos que las inquietudes formales de una empresa artística aún joven como la fundada por los pioneros del cine europeo y estadounidense allá en los comienzos del siglo xx establecen con otras propias de «artes mayores» como la de las letras. A fin de cuentas, el cinematógrafo, al igual que la narración literaria gestada desde la época de las antiguas epopeyas, parte de una fábula que contar — tal como vio tempranamente Sklovski (1971: 56)—, esto es, parte de un material diegético que, en su adaptación

1 Para la influencia del cine de Eisenstein en las novelas de Dos Passos, véase Seed (2009: 128-150).

2 A juicio de Villanueva (1994: 216), aspectos compositivos de las películas, tales como el flash-back (inversión temporal), el crossing-up y el cross-cutting (relato intercalado que permite la simultaneidad), las panorámicas como las de El acorazado Potemkin (1925), el close-up (primer plano), los zooms o los travellings, están ya presentes en algunos textos literarios del siglo XIX o de épocas anteriores, como las narraciones helenísticas. 
a la gran pantalla, se transforma al hacer un recorrido que va desde la concepción primigenia del argumento fuente al guion, que luego traducirán los realizadores en imágenes visuales y sonoras. Pero este guion, como la literatura, es, en primer término, palabra escrita, solo que, como puntualiza también Pérez Villarreal (2001: 13), se reescribirá más tarde «en el proceso del filme y se trastocará por una luz, un gesto, un decorado o una música; y es ahí donde para muchos estudiosos se demuestra mejor el proceso de interacción entre cine y literatura, sin olvidar por supuesto la herencia y la presencia del teatro [...]».

El hecho de que, desde mediados de los años $60 \mathrm{y}$, sobre todo, de los 70, se venga trasponiendo a la investigación del cine muchas de las consignas metodológicas concebidas originariamente para la explicación de textos narrativos revela las coincidencias entre el discurso literario y el del cine, más allá de sus respectivas especificidades. Agrupados en dos bloques separados, estos trabajos de narratología cinematográfica unas veces profundizan en el nivel de la historia, en el universo de ficción creado por el relato, mientras que otras indagan en el nivel del relato (Pérez Bowie, 2008: 32) ${ }^{3}$.

Llegados a este punto, es hora de que nos preguntemos por las clavijas que Chandler y otros maestros de la literatura negra anglosajona, en principio ajenos a la industria cinematográfica, accionan para compatibilizar los goznes articulatorios que enlazan sus narrativas con un medio en el que no terminan de encajar. En estos anclajes que habrán de incidir tanto en el contenido de la narración como en la gramática del texto intervienen factores heterogéneos que operan sobre un terreno doblemente abonado: por un lado, las novelas y los cuentos del género negro suministran abundante material para la ejecución de obras artísticas de otra especie que van a fecundar los

3 Dos de los precursores en este campo de los estudios cinematográficos son Chatman (2013) y Vanoye (2005), cuyas obras aparecieron en fechas próximas. Story and Discourse (1978), del primero, bucea en el intercambio entre destinador y destinatario del filme; reconociendo su deuda con los estructuralistas franceses, el teórico traslada el acento desde las características generales de la narratividad hasta el objeto en que se encarnan, el relato, y hasta el acto que les da cuerpo, la narración. Por su parte, el segundo ofrece en Récit écrit, récit filmique (1979) otro de los primeros intentos de análisis sistemático de algunas facetas del relato en el cine (focalizaciones, temporalidad...), tomando como punto de partida los conceptos de narratología literaria formulados por Genette, Greimas y Todorov, que por aquel entonces estaban en pleno desarrollo. El interés creciente de Chatman, que se orienta tanto hacia la literatura como hacia el cine, lo mismo que el de Vanoye, centrado tan solo en la esfera del séptimo arte, por la naturaleza enunciativa del discurso en detrimento del interés por la historia en su vertiente textual, abrirá un prolífico camino que después seguirán explorando Bordwell (1996), Gaudreault y Jost (1995), Sánchez Noriega (2000), Neira (2003), Stam (2009) o Sánchez Navarro (2006), entre otros. Un esclarecedor panorama de este tipo de acercamientos lo encontramos en Pérez Bowie (2008: 31-50). 
cimientos de un imaginario popular aceptado por millones de espectadores $^{4}$; por otro, el propio cine — con un énfasis no encauzado exclusivamente hacia la estética noir - contribuye a la fijación de unos códigos genéricos, mediante el uso de hallazgos visuales, iconográficos, movimientos de cámara, diálogos, puestas en escena, creación de estereotipos..., que acabarán traspasándose al ámbito de la literatura escrita. Porque, con independencia de que ciertos canales de comunicación masiva - y el cine es uno de ellosse hayan nutrido y se nutran todavía hoy del arte verbal (novelas, piezas teatrales..., que representan hipotextos atrayentes para algunos directores de películas), es innegable el giro que la narrativa contemporánea ha efectuado hacia un resuelto hibridismo intermedial desencadenado a partir de los procesos cinematográficos, además de las variadas reacciones que este suele experimentar ante un entramado artístico colectivo, que, con el entretenimiento como una de sus principales bazas, orienta subliminarmente la adhesión del público receptor a una ideología y a una manera de mirar el mundo y de relacionarse con él.

En el caso que nos ocupa, tres condicionantes posibilitan los trasvases en uno u otro sentido:

a) La globalización de la cultura del cine, que empieza al clarear el siglo $\mathrm{xx}$ y que despunta primero como una mera distracción de las clases trabajadoras hasta convertirse, una década después, en pasatiempo idóneo para el conjunto de la sociedad, sin distinción de estratos sociales ${ }^{5}$.

b) La irrupción de la escuela realista de narrativa policiaca cuyo hito fundacional se sitúa en los relatos de Carroll John Daly en torno al detective duro Race Williams, escritos desde 1922, es coetánea al surgimiento del film noir, modelado a partir de los años 30 y 40, con algunos antecedentes en las historias de gánsteres del cine mudo ${ }^{6}$, hasta el grado de que algunas de estas películas de tenor comercial provienen de la adaptación de textos literarios a la gran pantalla.

4 Es notorio que los thrillers americanos de detectives y crímenes que se popularizaron en revistas tales como Black Mask y otras o a partir de los textos de Hammett, Cain, Chandler o Burnett ayudaron a fijar un estilo que cristaliza en la modalidad cinematográfica negra.

5 El triunfo democratizador del cine como artefacto cultural es equiparable al que obtendrían - aunque en menor escala-, a partir de los años 20, las revistas pulp durante un paréntesis crítico de descalabro económico, cuando eclosiona una imperiosa necesidad de evasión en los Estados Unidos y se registra un sensible descenso de la tasa de analfabetismo. El auge de la literatura negra y de otros géneros populares —aventuras, romance, ciencia ficción...- hay que buscarlo precisamente en el éxito de estas publicaciones efímeras y baratas hechas con pulpa de madera; de ahí el nombre con el que se las conoce.

6 Piénsese en Underworld (1927) y The Dragnet (1928), de Josef von Sternberg, y en The Racket (1928), de Lewis Milestone. 
c) Si bien comúnmente se tiene por una experiencia desalentadora — según la han evaluado sus protagonistas-, lo cierto es que algunos representantes de la novela negra de las primeras generaciones trabajaron sin excesivo entusiasmo en algún estudio de cine pergeñando guiones propios y ajenos bajo la dictatorial mirada de productores y magnates. Y resulta llamativo que, pese a ser el aliciente económico el que motivó en gran medida el desempeño de esta actividad, de algún modo esta debió de dejar más de una impronta en la composición de las ficciones de estos autores.

\section{Chandler versus Hollywood: una relación de amor/odio}

Dotado de una sólida poética narrativa y con tres novelas ya en su haber, Chandler viene a ser uno de esos autores que, en permanente conflicto con sus inclinaciones personales, sucumbe a los cantos de sirena de Hollywood, donde ejercerá de guionista durante varios años. Algunas declaraciones suyas de esa época manifiestan una actitud marcadamente ambigua respecto al cine como industria y como disciplina artística. En su ensayo «Oscar Night in Hollywood ${ }^{7}$, se resiste a desacreditarlo en términos generales: «El cine no es solo un arte, sino que es el único arte completamente nuevo que ha evolucionado en este planeta de cientos de años. Es el único arte en el que los de nuestra generación tenemos alguna posibilidad de destacar, y mucho» (Chandler, 2013: 387). Que se le considere una distracción para el vulgo, agrega, no da derecho a nadie a menospreciarlo, pues, si nos remontamos al pasado, descubrimos que la tragedia griega fue también un entretenimiento de masas entre los antiguos atenienses, como lo fue asimismo el drama isabelino para los londinenses de los siglos XVI y xvII; sin embargo, hoy nadie le discute el lugar preponderante que ocupa en la historia de la dramaturgia universal.

De otra parte, el cine aventaja a la pintura, a la música, a la arquitectura, a la escultura y a la literatura en un aspecto: habida cuenta de su novedad, a finales de los años 40, que es cuando escribe Chandler, no estaba aún tan condicionado por el peso de la tradición, por lo que disponía de un espacio virgen de actuación superior al de la secular écriture literaria para explorar nuevas vías de lucimiento. Sin embargo, en el mismo texto, destinado a desmitificar la ceremonia de entrega de los premios de la Academia de Hollywood, asevera también que la mayor parte de las películas rodadas en la Meca del Cine descuella por su dudosa calidad y que los criterios de los académicos para decidir a cuál otorgar el ambicionado galardón poco tienen que ver con el valor artístico del filme.

7 Publicado en Atlantic Monthly (marzo, 1948). 
En cuatro de sus primeros relatos, Chandler tematiza ya, un tanto soslayadamente, algunos de los obstáculos que afrontan los profesionales del cine de la época, damnificados por el asomo de la violencia ${ }^{8}$ : la extorsión y el secuestro de una conocida actriz en «Blackmailers Don't Shoot», el asesinato de un director de películas pornográficas al que una organización de malhechores había chantajeado en «Smart-Aleck Kill» ${ }^{9}$, el embrolloso plan que fragua un galán de cine en horas bajas para llamar la atención de la prensa y del público con fines meramente publicitarios en «Pick-up on Noon Street» ${ }^{10}$ o el acribillamiento en plena calle de un personajillo del hampa del que se cuenta que había sido aspirante a actor en «The Curtain»"1.

No obstante, será después de editar un buen ramillete de narraciones breves en las revistas pulp de los años 30 y de publicar sus tres primeras novelas cuando Chandler conozca de cerca la siniestra maquinaria de la factoría del cine y cuando su inquina hacia Hollywood, esa «ciudad del pecado», como la califica la periodista amateur Birdie Keppel en The Lady in the Lake (1942) (Chandler, 2012: 576), se recrudezca.

La Paramount reclama en 1943 al autor de The Big Sleep (1939) para que preste sus servicios como escritor de guiones a sueldo ${ }^{12}$, lo cual acarreará enseguida un desasosegante estado de descontento y malestar del que ha dejado testimonio por escrito. En un artículo de 1945, «Writers in Hollywood»13, se queja de lo mal pagados que están casi todos los escritores que trabajan para el cine, aunque se apresure a admitir que muchos de los que reciben unos honorarios medianamente dignos carecen de las facultades que les permitirían ganarse el sustento en otro puesto de trabajo. Aprovecha para denunciar el hastío que le provoca su contacto con un negocio más obsesio-

8 Para entender estos y otros cuentos, no debemos perder de vista su adscripción a la línea policiaca hard-boiled, aquella que comprende un subgrupo de narraciones que, además de hacer gala de un «contenido de crítica social y política implícito en la descripción de los sórdidos ambientes en los que transcurren», despliegan otras cualidades como la «[n]arración en primera persona, lenguaje duro, uso de argot callejero, cinismo profundo en el carácter de un detective protagonista que está de vuelta de todo, pérdida de importancia del proceso de identificación del culpable, y unos rasgos estoicos y, a veces, nihilistas en la filosofía vital del detective» (Bartual, 2007: 98; cursiva del autor). Para profundizar en esta vertiente textual, véase Hamilton (1987), Smith (2000), Moore (2006) o González de la Aleja (2006).

9 Ambos publicados en Black Mask (diciembre, 1933 y julio, 1934).

10 Originariamente titulado «Noon Street Nemesis» (Detective Fiction Weekly, 30 de mayo de 1936), el autor decidió cambiarle el título al publicarlo en la colección The Simple Art of Murder (1950).

11 Publicado en Black Mask (septiembre, 1936).

12 El primero que firma con su nombre, elaborado conjuntamente con el director Billy Wilder, es el de la versión cinematográfica de la novela de James M. Cain Double Indemnity (1943).

13 Publicado en Atlantic Monthly (noviembre, 1945). 
nado con el capital que genera que con la realización de auténticas obras de arte. Es así cómo, subsumido en un círculo de fuerzas adversas contra las que ha de bregar machacantemente para hacer prevalecer su criterio, el guionista, proletario de la industria cinematográfica, autor desindividualizado, lamenta la imposibilidad de producir lo que quiere y cómo quiere, ya que, por encima de él, toda una legión de individuos con nombres y apellidos se encarga de supervisarlo todo y de ordenar que se modifique cuanto se le antoje. Historiadores autorizados ratifican este desamparo padecido por los guionistas en los estudios. Gabler (2015: 460) documenta que «[e]n Hollywood, los escritores eran contratados para proyectos que no eran y que nunca serían el producto de una sola sensibilidad, mucho menos las suyas». A causa de los incontables filtros por los que había de pasar el guion antes de recibir el anhelado visto bueno, este era objeto de tantas manipulaciones que acababa por desvirtuarse la primera versión del texto. Por consiguiente, sin poder individual de decisión, atados de pies y manos y sin esperanzas de obtener algún honor por una tarea sobre la que apenas ejercían algún control, los guionistas hollywoodenses eran meras comparsas a expensas de los caprichosos gerifaltes de las compañías cinematográficas.

En «Ten Percent of Your Life» ${ }^{14}$ embiste contra los agentes literarios, a los que tacha de personas mediocres y sin ética, seres habituados a manejar considerables sumas de dinero, ostentosos hasta la vulgaridad y derrochadores. A él ninguno de estos altos cargos puede encandilarlo con sus triquiñuelas, pues, escondido tras una fachada de respetabilidad y una encantadora sonrisa, se adivina un sujeto emocionalmente frío que solo piensa en términos monetarios $^{15}$.

Teniendo en cuenta esta coyuntura, se impone la impresión de que las aptitudes literarias del guionista de cine pasan a un segundo plano, ya que, en caso de que este gozara de algún don para la creación de altos vuelos, los mandatarios de los estudios se esforzaban en cercenarlo, con el perjuicio para el producto final que terminará cristalizando en platós y salas de montaje. Como nos recuerda Gabler (2015: 460):

[1] os escritores distinguidos no eran contratados por su talento literario, que, en cualquier caso, por lo general demostraba ser desdeñable en el peculiar arte de la escritura de guiones. Los escritores distinguidos eran contratados por la distinción que aportaban a los hombres que los contrataban. Como

14 Publicado por primera vez en Atlantic Monthly (febrero, 1952).

15 Lo define como «un traficante de talento, [...] casi nunca respeta ni comprende el talento como tal. Lo único que le interesa es su valor en el mercado [...]. Ronda por los estudios, los restaurantes y los clubs nocturnos, con las orejas estiradas a la caza de chismes y los ojos siempre buscando incansables una cara nueva o importante» (Chandler, 2013: 434). 
Jack Warner presumió en una fiesta tras contratar a William Faulkner: «Tengo al mejor escritor de los Estados Unidos por trescientos dólares a la semana».

Chandler, lo mismo que Faulkner y otros, se inscribe en esta perversa casuística. Es cierto que los estudios le abonan miles de dólares con los que puede cubrir sus necesidades básicas, incluso costearse unos cuantos caprichos, pero a cambio deberá renunciar a algo esencial de su propia idiosincrasia. De ahí que en otro texto emblemático escrito cuatro años antes para Screen Writer, pero que no llegó a publicarse — «A Qualified Farewell»pontifique que «el uso creativo del talento, que es la base imprescindible de la industria del cine, es algo que los que mandan no entienden en absoluto; de lo contrario, hace tiempo que habrían procurado crear las circunstancias para que pueda florecer» (Chandler, 2013: 407). En el mismo artículo apostilla con dureza que el mejorable estatus artístico de la mayoría de las producciones hollywoodenses, películas en las que prima el escapismo, hechas a base de lugares comunes y que evitan mostrar temáticas incómodas, obedece al reparo de los y las guionistas a enfrentarse a las exigencias de productores descerebrados por temor a que sus contratos sean rescindidos (Chandler, 2013: 403) ${ }^{16}$.

Si no puede ser más taxativo que en los postulados vertidos hasta aquí, sí logra un ápice mayor de incorrección política en la carta privada, espacio de la intimidad en el que, libre de los impedimentos que frenaban su áspera marejada de indignación, Chandler se desahoga a sus anchas. En una carta del 12 de enero de 1946 dirigida a su entonces editor Alfred Knopt, lanza dardos envenenados contra el idealismo artificial que preside la colonia de Hollywood, contra el «entusiasmo simulado», «las trampas mezquinas», «la bebida y el sexo constantes, las incesantes riñas por dinero», la intromisión de los agentes en el trabajo de los guionistas, el pavoneo y la incompetencia de los directivos, el terror a que sus fortunas se volatilicen de un día para otro y que sus dueños pasen a engrosar la lista de «nulidades que en realidad nunca dejaron de ser»; en definitiva, bosqueja un triste horizonte de corrupción, vanidad y locura que «no es de este mundo»(Chandler, 2013: 85-86).

Dos son las causas, entonces, que determinan los prejuicios del escritor hacia el cine hollywoodense: por un lado, las inaceptables condiciones de producción (industrial y colectiva) de las obras cinematográficas y, por otro,

16 Fuera del caché que confería a los estudios de cine que los reclutaban, los literatos no ocupaban una posición significativa en Hollywood; de carácter reservado, casi no intervenían en la escena social de la ciudad. Uno de los pocos sitios que frecuentaban era el Musso \& Frank Grill, restaurante ubicado en Hollywood Boulevard, al lado del cual había una librería donde solían reunirse para hablar de literatura. 
las circunstancias de su recepción, derivadas de la heterogeneidad y los gustos controvertibles del público de masas, al que se busca complacer.

No pocas de estas invectivas diseminadas en artículos y en su producción epistológrafa las camufla el escritor en The Little Sister (1949), su quinta novela. Si bien no es esta una de sus mejores obras, en ella las intrigas que hacen de la capital mundial del cine un destino «apocalíptico», ubicado en las antípodas del sueño americano, se suceden en cadena; desde sobornos, envidias entre compañeros de oficio, batallas dialécticas en el set de rodaje, reacciones descontroladas y patéticas para hacerse con un rol secundario en una película, hasta coqueteos de la gente de la farándula con la mafia, una oscura realidad que en los últimos años ha destapado Adler ${ }^{17}$. En The Little Sister, un híbrido fronterizo entre la narrativa policiaca «dura» y la categoría conocida como Hollywood novel, se hacen descarnadas incursiones en la vida irregular de los intérpretes; se reflexiona sobre la escasa dignidad artística de las películas, en gran parte sin personalidad, diseñadas con objetivos puramente comerciales; sobre el modo estandarizado en que el drama y el suspense se cohesionan para halagar las emociones de un consumidor poco exigente o sobre el ridículo valor del dinero, que los ejecutivos despilfarran a espuertas. Según Rhodes (2008: 82), The Little Sister es, además, un inventario de conflictos en el que el individualismo radical y el populismo se dan la mano, dos creencias antagónicas que, sin embargo, consiguen equilibrarse y conectar con la teoría de la fantasía del último Freud, más específicamente en lo que se refiere a los principios contrastantes del placer y de la realidad.

Por supuesto, como en toda historia de detectives que se precie, aquí hay también muertes, muertes sangrientas, además de sexo. A este propósito, Jules Oppenheimer, propietario de más de mil cines y de unos grandes estudios, sopesa este ingrediente tan consustancial a Hollywood desde su fundación: «Demasiado sexo [...]. Está muy bien en su momento y en su lugar, pero aquí lo tenemos a carretadas. Chapoteamos en él. Estamos hasta el cuello. Acaba siendo como el papel matamoscas» (Chandler, 2012: 802). Cuando Philip Marlowe visita uno de esos enclaves en busca de la actriz Mavis Weld, pregunta al vigilante de seguridad si el cristal de la puerta está hecho a prueba de balas, a lo que este le responde: «-Pues claro. ¿Por qué?

17 Según Adler (2008: 15), la industria de Hollywood «siempre se ha basado en una realidad criminal. La mafia ha intimidado a actores y productores con amenazas y violencia hasta hoy y desde la década de 1930 — cuando extorsionaba a los estudios con un millón y medio de dólares al año [...]—». Señala además que «[1]a mafia se sintió atraída por la industria cinematográfica en parte porque había mucho dinero por ganar y en parte debido a su glamour (los gánsters eran famosos ya de por sí, y a menudo salían mencionados en las columnas de sociedad)»(Adler, 2008: 69). 
- Por pura curiosidad [...]. Nunca he sabido de nadie que intentara entrar a tiros en la industria del cine». Una chica atenta a la conversación interviene para expresar en tono sarcástico: «-Ay, amigo, si bastara con pegar tiros...» (Chandler, 2012: 801).

Si nos atenemos a esta visión del Hollywood de su tiempo, no es de extrañar que MacShane (2017: 198), uno de los biógrafos de Chandler, opine que el escritor chicagüense trataba de vengarse con esta novela de todos los sinsabores que tuvo que soportar mientras realizaba trabajos alimenticios en la Meca del Cine.

\section{El dí́logo con la gran PANTAlla: citas, confluencias}

Al margen de los compromisos de Chandler y de sus frustrantes obligaciones para con los estudios, situación análoga a la de otros colegas suyos que trabajaban en la parcela supuestamente más creativa del espectáculo cinematográfico, aún le sobran energías para engarzar al colorido lienzo de narrativa noir que confecciona un estilo y un lenguaje que se imbrican con la hechura del cine negro clásico; un género que, según se puede constatar, debuta durante y después de la II Guerra Mundial con una ristra de películas protagonizadas por carismáticos sabuesos y por hombres que arruinan sus existencias por culpa de alguna astuta mujer - The Maltese Falcon (1941) de J. Huston, Double Indemnity (1944) de B. Wilder, Detour (1945) de E.G. Ulmer, The Killers (1946) de R. Siodmak...-, a las que se suman como precedentes germinativos del género los filmes de gánsteres de los años 30, que muestran la lucha contra el crimen organizado: Little Caesar (1931) de M. Leroy, The Public Enemy (1931) de W.A. Wellman, Scarface (1932) de H. Hawks... ${ }^{18}$

La interferencia en la narrativa chandleriana de actantes, espacios, temas y problemáticas de aroma hollywoodense es bien patente. Valga aclarar que, si las películas que se alimentan de las ficciones de este autor, así como de las de Hammett, Burnett, Woolrich, MacDonald o Cain, por mencionar a aquellos cuyas obras se trasladaron a la gran pantalla en varias ocasiones, trasvasan a los guiones y a la imagen óptica que visionará después el público en una oscura sala de cine una buena cuota de la sustancia argumental del objeto literario reconfigurado en producto decididamente cinematográfico ${ }^{19}$, es indiscutible también que muchas de las convenciones narrativas de la literatura policiaca, en cuanto a motivaciones, atmósferas, caracteres, resortes

18 Para Heredero y Santamarina (1996: 21), el cine de gánsteres y el cine negro constituyen modelos genéricos diferenciados.

19 Algunos de los títulos enumerados más arriba son, efectivamente, adaptaciones de obras de Burnett, Bright, Armitage Trail, Hammett, Cain, Goldsmith o Hemingway. 
estructurales e ideología se refiere, se solapan con otras desarrolladas en el contexto comunicativo del cine. No en vano, los mismos rasgos que Arribas (2010: 14) adjudica al género cinematográfico negro del periodo clásico se deslizan en la escritura novelesca de idéntica tipología, caracterizada igualmente por la participación de delincuentes, mafiosos, agentes de la ley, investigadores privados o vampiresas de medio pelo:

[...] historias sobre mentiras e infidelidades, sobre ambiciones y deseos ocultos, sobre grandes derrotas y tristes victorias, sobre el lado oculto de ese extraño entre nosotros que es el ser humano. Son historias fatalistas, sobre una sociedad corrupta y violenta, falsa e hipócrita, en las que el pasado tiene un peso que siempre aboca al fracaso. Son imágenes en claroscuro, tenebrosas, claustrofóbicas, nocturnas y lluviosas.

Murder, My Sweet (1944), adaptación fílmica de Farewell, My Lovely (1940), respeta en su mayor parte los hipotextos de la fuente original en la que se basa, sin pretender una literalidad exacta. Exceptuando la suavización de los componentes más crudos de la historia primigenia o de la denuncia contra la corrupción, que en la pantalla se atribuye más a errores individuales que a defectos del sistema, o el que se le dé mayor presencia a la relación sentimental entre Marlowe y el personaje de Ann Grayle, Edward Dmytryk, director de la cinta, trata de buscar correlatos visuales a cada una de las sensaciones que el detective trasmite en el libro. Así, donde en la novela Marlowe habla de que todo "se volvió negro", en la película aparece como un plano que se va llenando de una especie de tinta oscura. En la escena en la que el sabueso está bajo el efecto de las drogas que le han inyectado en la clínica del curandero Amthor, se interpone entre la cámara y el personaje un cristal «sucio» que traduce en imágenes esa turbia humareda que aquel cree ver y que se esfuma una vez que su mente se despeja. Por añadidura, la película se salva de mayúsculas «traiciones» reteniendo la focalización de la primera persona gramatical a través de una voz en off (la de Marlowe) que exterioriza el lenguaje fresco y colorido propio del estilo chandleriano y que garantiza la subjetividad perceptiva de los acontecimientos. En un esfuerzo por mantenerse próximo a la obra literaria, John Paxton, guionista del filme, incorpora trozos completos del «relato de palabras» (o discurso en boca de los personajes), como en la escena en la que el detective y Amthor se confrontan para determinar la naturaleza de su vínculo con Helen Grayle, hermana de Ann, y el segundo expresa su desdén hacia el honesto investigador privado en unas líneas extraídas de la novela ${ }^{20}$.

20 Véanse Pendo (1976), Luhr (1991), Clark (1996) o Phillips (2000) para obtener más datos sobre las adaptaciones de las obras de Chandler al cine. 
Al cotejar estos sustratos germinados de campos ficcionales desiguales pero que interactúan entre sí, advertimos indicios factibles de cómo la creación literaria noir imprime su sello en su homólogo cinematográfico, y a la inversa. Los resultados al respecto saltan a la vista tanto en el marco de la historia como en la morfología de una modalidad escritural como esta, a la que, por cierto, la crítica especializada tardaría muchos años en reconocerle alguna funcionalidad artística ${ }^{21}$. Entre uno y otro sistema de representación semiológica - predominantemente icónico el cine, simbólico la literatura - se extienden vastas redes de interdiscursividad, persistentes casos de flujos y de dialogismos que transcodifican y resignifican alguna instancia, unas veces sutilmente, otras no tanto, en la superficie espejeante de la narración policiaca, si no en el subtexto mismo del producto fictivo, ya se trate de una imagen fotográfica animada, ya de un fragmento de discurso escrito, sin que la incógnita acerca de la génesis que subyace en cada una de las contribuciones que entran en juego se despeje satisfactoriamente.

El término interdiscursividad se pone en circulación a partir de 1982 en los estudios de Segre $(1982=1984)$ sobre la novela y la poesía. El crítico italiano se refiere con esta noción a un fenómeno que permite aglutinar bajo un mismo paraguas todo un sistema de relaciones dialógicas que afectan a distintos órdenes disciplinarios (música, ciencia, pintura, literatura...). En opinión del estudioso, la palabra interdiscursividad designa «las relaciones que cualquier texto, oral o escrito, mantiene con todos los enunciados (o discursos) registrados en la correspondiente cultura y ordenados ideológicamente» (Segre, 1984: 111) ${ }^{22}$. Este concepto, acuñado como categoría útil para abordar los encuentros entre el texto literario y obras pertenecientes a otras artes, es pariente del vocablo intermedialidad, nacido más o menos por los mismos años y que describe también la interacción de formatos de comunicación disímiles que convergen en algún punto del ejercicio creativo para enriquecerse mutuamente (Plett, 1991: 20).

La interdiscursividad y la intermedialidad, en tanto que señas de identidad del arte contemporáneo, son herramientas conceptuales singularmente rentables para el análisis de la obra de Chandler. Por ejemplo, al comentarle el detective Denny a su colega Johnny Dalmas en «Smart-Aleck Kill» ${ }^{23}$ que actúan «[i]gual que en las películas» (Chandler, 2010: 82), aludiendo con ello a los métodos que ambos diseñan para dar con el paradero del asesino

${ }_{21}$ Dos de los primeros teóricos que empezaron a darle alguna relevancia al género narrativo policiaco, que antes se solía incluir en apartados tales como «literatura de consumo», «paraliteratura», «subliteratura», etc., son Eco (1964) y Todorov (1971).

22 La traducción del original es nuestra.

23 Cuento publicado en Black Mask (julio, 1934). 
de Derek Walden antes de que la policía descubra el cuerpo sin vida del director de cine porno, se pone el acento en una voluntaria filiación de reminiscencias filmográficas que subraya la intención de que el relato se lea cinematográficamente. El parangón con el mundo del celuloide, base de este aporte de cariz interdiscursivo, presupone aceptar una deuda que la ficción negra contrae históricamente, dentro de la era de la cultura de la imagen, con ese tinglado de luces y sombras que, al centellear sobre el panel blanco de la pantalla, remueve la fantasía de un auditorio pasivamente entregado, cuando no desvela el transcendente papel que el cine, en cuanto expresión artística y sociológica de los mass-media, tiene en la época moderna, sobre todo durante el periodo previo al advenimiento de la televisión y, especialmente, de Internet, dos medios que harían descender considerablemente el número de espectadores en las salas.

Con su impredecible capacidad de difusión y de embaucamiento, semejante a la que Platón adjudicara a la poesía siglos atrás, el cine llega a latitudes y a sectores sociales a los que no tiene acceso la ficción literaria. En nuestros días un porcentaje de los espectadores, en particular los más cinéfilos, asocia In a Lonely Place con la estampa en blanco y negro de un Humphrey Bogart en el papel del guionista en crisis del que se sospecha que ha dado muerte a la chica del guardarropa del bar al que solía acudir; en cambio, la novela homónima de Dorothy B. Hughes en la que se inspira la película dirigida por Nicholas Ray, sin que les neguemos sus muchos méritos, ¿Cuántas personas la recuerdan fuera de las fronteras norteamericanas? En este sentido, los textos que nos ocupan, si bien impregnados de censurable misoginia y hasta de homofobia, pero reeditados y traducidos a muchos idiomas una y otra vez, han tenido una mayor proyección, en cuanto al número de lectores concierne, que el más insólito punto de vista feminista de Hughes. Sea como fuere, la huella de la visión cinematográfica revierte en todas sus constelaciones enriqueciendo la textura de ambas obras, tanto en su dimensión estética como pragmática. De acuerdo con el modelo establecido por Chandler, «oímos» en más de una ocasión la voz de Marlowe sugiriendo narrativamente, siempre que se lo propone, un parentesco entre sus gestos y los de las luminarias del cine, como cuando en The Little Sister acepta la petición de búsqueda del hermano de Orfamay Quest y le responde a esta «con una voz que sonaba como la de Orson Welles, con la boca llena de galletas»(Chandler, 2012: 781)24. Del astrólogo de Farewell, My Lovely se nos cuenta también que «[1]levaba el pelo hacia atrás, sobre un perfil que

24 El nombre de este enfant terrible de Hollywood ha quedado asociado al cine negro desde que en 1947 dirigió y coprotagonizó, junto a su todavía esposa Rita Hayworth, The Lady from Shanghai, película en la que encarnaba a un marinero irlandés que se ve atrapado en una maraña de intrigas y asesinatos. 
nada tenía que envidiar a la mejor época de John Barrymore» (Chandler, 2012: 267).

La comparación del físico, la vestimenta o los modales o actitudes de un personaje dado de la ficción con los de algún actor de reconocido prestigio es una estrategia recurrente que no se distancia mucho de lo que Stam (2001: 242) denomina «intertextualidad de las celebridades». Como ardid apto para omitir trazos de prosa innecesarios, este recurso del símil realza las posibilidades del texto detectivesco a partir de una cinefilia generalizada que se le presupone al receptor ${ }^{25}$.

No faltan casos en que se saca a relucir de los personajes un pasado con aspiraciones artísticas. Otras veces vemos a estos dedicándose al cine, como Mavis Weld y Dolores Gonzales en The Little Sister, Alex Morny en The High Window (1942), Larry Batzel en «The Curtain» o el afeminado Lindsay Marriott, que terminaría asesinado en Farewell, My Lovely. Este había solicitado los servicios del especialista en ciencias ocultas Jules Amthor para que le aplicase un tratamiento que erradicase su timidez ante las cámaras. De poco sirvió ese esfuerzo, refiere Amthor: «El cine no estaba interesado en él», a lo que nuestro detective añade cruelmente: «-Eso lo entiendo [...]. En la pantalla hubiera parecido Isadora Duncan»(Chandler, 2012: 268).

En una de sus visitas a una anciana adicta al chismorreo, Marlowe y el policía que lo acompaña se quitan el sombrero para comentar a renglón seguido: «En aquella barriada, aquel gesto nos puso probablemente a la altura de Rodolfo Valentino»(Chandler, 2012: 305).

Detrás del sarcasmo y de los irónicos incisos, se inyecten o no de prurito fílmico, se posiciona sin reservas la voz narradora tanto para ensalzar a un ente de ficción como para degradarlo, por muy hermoso que a simple vista resulte su envoltorio. En Farewell, My Lovely la señora Lewin Lockridge Grayle aparece desde el principio luciendo una estela de decadencia a la manera

25 Este patrón deviene un cliché estilístico en las obras de otros muchos autores de novela negra que, lo mismo que Chandler, escriben para una comunidad de lectores cuyos principales referentes se hallan en el cine. El dueño de un bar de Pacific Way al que llega para telefonear y comer algo el detective Jack LeVine en la novela Hollywood and LeVine (1975) de A. Bergman (1983: 50) «le sonrió y dejó al descubierto una dentadura tan perfecta como la de Dick Powell», cantante y actor versátil, quien, por cierto, interpretó a Marlowe en la película Murder, My Sweet de Dmytryk. En The Case of the Negligent Nymph (1950), de E.S. Gardner, la joven Dorothy Fenner, a la que va a visitar Alder, máximo accionista de una compañía petrolífera, para llegar a un acuerdo después de que la denunciara por un falso robo en su domicilio, adopta una pose que recuerda la de una actriz entrevistada por un periodista. No siempre el personaje sale bien parado con el contraste. En The Case of the Careless Kitten (1942), también de Gardner, el rostro de George Alber, uno de los pretendientes de Helen Kendal, se parece a una foto de un actor de cine, pero retocada, lo cual desagrada a la muchacha, que está enamorada de otro hombre. 
de una femme fatale de segundo orden, título que los sucesos posteriores no harán más que avalar: "Parecía tan solo una mujer que podría haber sido peligrosa cien años antes, y osada hacía veinte, pero que en la actualidad no pasaba de serie B hollywoodense»(Chandler, 2012: 357).

En The Little Sister, en concordancia con el tema que desarrolla, se insinúa una proximidad entre la imaginación novelesca y la inventiva de orden cinematográfico. Una de las conversaciones entre el detective y una Mavis Weld pálida y temblorosa se desenvuelve como parte del rodaje de una mala película en la que ambos simulan ser los actores principales. La conveniencia de esta lectura, que encauzamos hacia esquemas fílmicos, se afianza en un momento preciso en el que el diálogo no evoluciona por los derroteros deseables y los personajes interpelan a la «escena» que imaginan estar representando:

—Yo... yo... - Se interrumpió e hizo un gesto de indefensión-. No recuerdo mis frases esta noche.

—Es el diálogo en tecnicolor — dije- Se te queda congelado (Chandler, 2012: 858).

Congelados y antinaturales parecen Marlowe y Weld en esta secuencia que prorrumpe cuando el primero arriba a la casona en plena noche y se halla a la segunda en estado catatónico, con un revólver en la mano y junto al cadáver de un matón del que había estado enamorada; un episodio que, al sumirse en una atmósfera de metafórica ritualidad, adquiere algo de simulación teatralizante. Los mismos «actores» que participan y que, a la vez, son testigos de esta farsa, parecen conscientes del aspecto irreal que toman las acciones que ejecutan; de ahí las alusiones autorreferenciales a los actos de habla que intercambian en su coloquio el sabueso y la actriz, lo mismo que el narrador autodiegético, identificado con uno de los dos personajes, el masculino:

Bajó la pistola a un costado y durante un momento se limitó a mirarme. Después arrojó el arma sobre el diván.

- Me parece que no me gusta el guion —dijo- No me gustan los diálogos. No siento el papel, no sé si me entiende (Chandler, 2012: 864).

Mavis, actriz que interpreta a una starlet en apuros, discute sobre la escena (¿de cine?, ¿de teatro?) en la que le ha tocado intervenir, como si no fuese responsable de lo que le sucede o de lo que hace, como si obrase impulsada por algún agente externo a ella, una suerte de guionista o de director que maneja, desde la sombra, los hilos de una trama en la que está escrito el destino incierto de la intérprete. El investigador, entregado también a una idéntica performance verbal y guionizada, se apodera del arma que sujeta la muchacha y comprueba que había sido disparada recientemente. Entonces ella le pregunta: «¿No va a envolverla en un pañuelo, como hacen en las 
películas?» (Chandler, 2012: 860), operándose nuevamente una equiparación entre lo que ocurre en el interior del texto y un leitmotiv procedente de una creación de índole cinematográfica.

Con la alusión a este método interdiscursivo que tiende a «audiovisualizar» los parlamentos de las figuras chandlerianas se corrobora el aserto de que, aun cuando los conflictos se desarrollen fuera de escenarios directamente ubicados en Hollywood y de los lugares característicos donde se actúa y se rueda, las estratagemas que se inspiran en la imagen fílmica, unidas a los apuntes de metaficcionalidad que complejizan el argumento, influyen en la gestación y planificación escritural, incluyéndose en ese binomio la presentación orquestada de diálogos en staccato, que tanto gustan a Chandler. Las menciones a los componentes de naturaleza cinematográfica y los paralelismos entre el cine y el texto literario, moneda corriente en el género narrativo policiaco, fundamentalmente el de la época clásica, se traducen en varios ramalazos de enunciación que podemos etiquetar de "cinemórficos", término que usamos aquí en la misma acepción que le da Marcus (1986: 2): «Con la palidez y las cicatrices de la cara, el cuello del abrigo levantado, el sombrero hundido hasta las cejas y la pistola, podría haberse escapado directamente de una película de gánsteres al viejo estilo» (Chandler, 2012: 922), anota Marlowe acerca del prófugo Terry Lennox en The Long Goodbye (1953).

En The Big Sleep, la primera novela de la serie, se describe también al chantajista Joe Brody acudiendo a un canon tipificado antes por el cine: «Su voz era la voz exageradamente despreocupada de los tipos duros de las películas. El cine los ha hecho a todos así» (Chandler, 2012: 65); comentario en virtud del cual cualquier receptor medianamente instruido en este terreno puede hacerse una idea del modo de hablar del personaje. Para la recreación de Brody no hacen falta datos prolijos: basta compaginar lo que dice literalmente el texto con una determinada imago asociada al séptimo arte. A la par, se deja entrever que gánsteres de cine como los interpretados por Humphrey Bogart o George Raft sirven de modelos a mafiosos reales, tanto en los gestos y en las formas de expresarse como en su vestimenta y en el modo de colocarse el sombrero o de sostener un cigarrillo.

Al elegir este modus operandi Chandler se suma a otros muchos exponentes de la novela negra que transitan por idénticos senderos. Así, MacDonald (1983: 178) en The Drowning Pool (1950): «Todo esto pasó por el ojo secreto de mi mente, como si fuera una película que hubiera sido rodada hace mucho tiempo. Solo faltaba sacarla de la lata y doblar el diálogo» ${ }^{26}$. En «Last Night»,

${ }^{26}$ En varias de sus novelas y cuentos — The Ivory Grin (1952), The Wycherly Woman (1961), «Find a Woman» (1946), «Gone Girl» (1953), etc.— se da la presencia del referente cinematográfico que permite al lector visualizar una escena e imaginarla a partir de criterios diegéticos fílmicos. 
una nouvelle de W. Irish, seudónimo del artífice de narraciones policiacas y de misterio C. Woolrich ${ }^{27}$, Jacqueline Blaine, aprovechando la ausencia de uno de sus inquilinos, registra su guardarropa, en el que no descubre lo que andaba buscando, pero sí un pequeño revólver y otros objetos, entre ellos un viejo recorte de periódico que informaba de la aparición de un cadáver bajo un puente. Al concluir sus pesquisas, la mujer sale sigilosamente de la estancia cerrando la puerta tras sí «con la curiosa sensación de haber presenciado unas cuantas escenas turbias de una película anticuada» (Irish, 2004: 140).

Y ya como epítome desenfadado de una de esas tramoyas que problematizan la endeble reputación de conocidos astros del cine con mucho que ocultar, se enmarca la pantomima de Errol Flynn en Bullets for a Star (1977), quien, restándole gravedad al chantaje del que está siendo víctima, adopta por un momento la actitud desafiante del héroe de The Adventures of Robin Hood, al que él mismo diera vida en el filme dirigido por M. Curtiz en 1938. La broma cautiva de tal modo a Toby Peters, el detective encargado de resolver el caso, que anota lo siguiente: «Durante un segundo fui un niño de diez años en una matinal de cine en vez de un lastimoso guardaespaldas por horas de cuarenta años con la nariz machacada» (Kaminsky, 1987: 25).

Enunciados de esta naturaleza, en los que la ilusión del texto novelesco se amalgama con la del cine al más puro estilo comercial, legitiman los matices transficcionales y cinemórficos de los que se imbuyen las obras chandlerianas. Es manifiesto que las palabras, con sus valores virtuales y simbólicos, evocan en la mente del lector los rasgos de cualquier personaje o del lugar u objeto descrito, o bien desenvuelven una escena que se relata mediante una tentativa de «cinematización» capaz de movilizar la realidad ontológica del texto sobre la base de posibles sinergias entre ámbitos estéticos desparejos. Las novelas y relatos de Chandler, tratando de postular una nueva vida - la imaginaria y paralela de la ficción- acercan el estatus de la literatura al cine, ya sea introduciendo en el espacio omnívoro de la obra algún motivo filmográfico o a Hollywood como trasfondo, ya procurando una simbiosis parcial de ambos canales artísticos. En The Long Goodbye un playboy pagado de sí mismo muestra una «sonrisa en cinemascope» (Chandler, 2012: 975), mientras que la servilleta de papel que extiende Marlowe en una bandeja cuando va a visitarlo Eileen Wade «[p]arecía tan hortera como un cuello de celuloide» (Chandler, 2012: 979) ${ }^{28}$. Como si la «mentira»

27 Este extenso relato apareció en la colección I Wouldn't Be in Your Shoes (1943).

28 Esta interesante mujer, casada con un escritor superventas, refiere en otro momento que el individuo que trae de vuelta a su marido a casa vestía «con un traje de vaquero como los que solo se ven en el teatro o en las películas musicales en tecnicolor»(Chandler, 2012: 981). 
del producto textual solo pudiese autentificarse o subsistir en relación con la fantasía que instituye una determinada obra de cine, el espacio de la novela se asemeja a otros emplazamientos formalizados en la gran pantalla. El vestíbulo del Idle Valley Club, en el que tenía concertada una cita Marlowe con el secretario del jefe de ese lugar en The High Window, «parecía un musical de alto presupuesto. Montones de luces y cosas brillantes, muchos decorados, mucho vestuario, mucho sonido, un reparto de estrellas y un argumento con toda la originalidad y la emoción de una uña rota» (Chandler, 2012: 451).

Tales interrelaciones fílmico-literarias en la narración, de tan reiterativas, acaban por volverse tópicas, a resultas de lo cual la sombra de la incertidumbre se cierne sobre el cañamazo de esas historias. Ello se debe a que, al sobreimponer a la ficción escrita una nota metadiscursiva y autorreferencial que congenia con una de las tendencias más sugestivas de un sector de la literatura criminal, tanto la de los primeros tiempos como la más reciente, el estatuto embrionariamente realista y la presunción de una objetividad de apariencia casi seudoperiodística se cuestionan. De acuerdo con tal criterio, lo que fluye desde las entrañas de la inventiva literaria se confronta con otro segmento del mundo imaginario adscrito esta vez al universo del fotograma, al soporte de la imagen en movimiento, a la magia de la pantalla de cine, ese artilugio encantador plagado de irrealidad «en el que se proyectan los deseos y los sueños de la mayoría», según Lipovetsky y Serroy (2009: 9). Ocasionalmente, el recurso al cine como táctica para comentar cierto incidente, apuntar una circunstancia o invocarse a alguien en particular se embadurna de una pátina de existencia verosímil pero que depende de la realidad empírica, como cuando le cuenta Marlowe a Joseph P. Sapo en The Little Sister, un personaje que pretende sobornar al detective, el episodio en el que un hombre dispara a otros dos que tenía enfrente por debajo de la mesa. Sapo replica: «-Eso lo he visto en una película [...]. -Exacto —dije yo-. Pero el tío que hizo la película me contó de dónde había sacado la idea. Y aquello no había sido ninguna película» (Chandler, 2012: 776).

En el relato «The Pencil», publicado inicialmente como «Marlowe Takes on the Syndicate» en una revista británica ${ }^{29}$, el investigador amenaza a Foster Grimes, el jefe de una banda de matones procedente de Las Vegas: «-Mire bajo la mesa, señor Grimes. Verá una 45 en la pistolera fija, apuntando a su barriga [...]. La bala de cuarenta y cinco puede hacerle saltar dos metros. Incluso el cine acabó aprendiéndolo» (Chandler, 2012: 1385). Un diálogo en el que se comprueba cómo el aparataje discursivo antecede

29 London Dayly Mail (abril, 1959). 
a su correlato cinematográfico, funcionando conceptual y cronológicamente como valencia mediadora para la mostración textual de otro medio divulgador de mayor influjo que, en un viaje de ida y vuelta, termina inspirándose en aquel.

Está claro que, durante su polémica etapa de cinco años bajo las órdenes de distintos estudios de Hollywood (Paramount Pictures, Universal, Warner Bros.), con los que colabora intermitentemente, Chandler se habitúa, muy a su pesar, al uso de procedimientos cinematográficos y a la fuerza cinética que desprende la cámara. El cine, con su impactante visualidad en blanco y negro o en color, con sus fableaux vivantes iluminados con una luz expresionista, con su ritmo atmosférico frenético, con su mirada fragmentaria, lo seduce sobremanera, aun cuando declare que, si se dedica a la escritura de guiones, es por dinero, y a pesar de confesar desconocer por entonces aspectos técnicos esenciales del cine. No obstante esas limitaciones, González-Cascos (1998: 112) ha señalado que, desde muchos años antes, no ignoraba, como otros muchos autores de su generación, que estaba creando para un público acostumbrado a este vehículo de comunicación de masas:

Desde los comienzos de su carrera, Chandler utiliza entornos, actitudes y personajes comunes para el público que va al cine y así ganarles como lectores. Puesto que la revista Black Mask estaba dirigida a lectores de una cultura limitada, tenía que utilizar muchas imágenes visuales. Chandler merece ser alabado por utilizar esta forma de unir películas de ficción y libros de detectives del mismo modo que el claroscuro. En este sentido vemos que Blackmailers Don't Shoot está en tonos negros, blancos y grises.

Compartimos este pensamiento, que exigiría un mayor desarrollo. Y no solo por los tintes y el cromatismo que el autor les infunde a sus creaciones, sino por el gusto que muestra por ciertos «encuadres» narrativos o la elección de ángulos de observación específicos desde los que se describen los hechos, por no hablar de los puntuales y explícitos guiños al formato cinematográfico, a algunos géneros del cine en particular o a los admirados ídolos del star system hollywoodense. De tales infiltraciones, que, a modo de intertextos, recalcan la sincronía de las diversas expresiones culturales que concurren se servirá el escritor hasta el final de sus días, tratando de satisfacer las expectativas de los destinatarios potenciales de sus obras. En The Long Goodbye, la penúltima novela que publicó en vida, durante la celebración de un cóctel party en el domicilio del escritor Roger Wade, tras las palabras del doctor Loring en las que proclama su abstemia y su rechazo a la gente que se propasa con el alcohol, su esposa, Linda Loring, hace la siguiente aclaración en un tono evocador: «Come Back, Little Sheba», en alusión a la película homónima, que en España se tituló Vuelve, pequeña Sheba (1952), dirigida por D. Mann, en la que Lola (Shirley 
Booth) es la esposa de Doc Delaney (Burt Lancaster), un alcohólico en vías de recuperación ${ }^{30}$.

En relación con las morosas alusiones geográficas y topográficas en I promessi sposi (1842) de Manzoni, comenta Eco (1996: 80) la posibilidad en el narrador de «detenerse en el texto y perder tiempo en él, para traducir el espacio», dilatando, «con respecto al tiempo de la fábula, tanto el tiempo del discurso como el tiempo de la lectura». Esta es una de las formas arquetípicas en las que se ubica algo bajo nuestra mirada, generando el efecto de que lo vemos pormenorizadamente; una sensación que se suscita a través de una figura retórica tradicional: la de la hipotiposis, que consiste en presentar las descripciones o los acontecimientos como si los lectores estuvieran delante de ellos, captándolos tal como se vería un reportaje filmado y haciendo que esas mismas estampas avancen mediante argucias como el zoom y el ralenti o cámara lenta, que el cine aprendió de la narrativa decimonónica. De este modo, el microcosmos espacial que el texto despliega se capta de manera vívida, algo así a como si visualizásemos un mapa o lo contempláramos a través de una lente en movimiento.

Variante de esta táctica en los confines de la escritura del siglo xx es la introducida por Chandler (2012: 264) en Farewell, My Lovely durante un periplo en coche en el que el detective realiza un «barrido» visual de las diferentes zonas de la geografía mítica de Hollywood por las que va pasando:

Recorrimos los dos o tres kilómetros deslumbrantes de la sección de Sunset Boulevard conocida como «The Strip», dejamos atrás las tiendas de antigüedades que llevan nombres de famosos astros de la pantalla, los escaparates llenos de encajes y de peltre antiguo, los lujosos clubs nocturnos de nueva planta con cocineros famosos y salones de juego igualmente famosos, regentados por elegantes graduados del Purple Gang, el sindicato de los bajos fondos de Detroit; dejamos atrás la moda arquitectónica georgiana-colonial, [...] los hermosos edificios modernistas en los que los comerciantes de carne humana de Hollywood nunca dejan de hablar de dinero, y también un restaurante para comer sin bajarse del coche que, por alguna razón, resultaba fuera de lugar [...]. Dejamos atrás todo aquello, hasta llegar, describiendo una suave curva amplia, al camino de herradura de Beverly Hills, las luces hacia el sur, todos los colores del espectro y una completa transparencia en una noche sin niebla; dejamos atrás las mansiones en sombra sobre las colinas del norte, atrás por completo Beverly Hills, hasta alcanzar el serpenteante

30 En la traducción española de la novela que hemos consultado se sustituye esta película por otra más conocida en nuestro país: Días sin huella (1945) de B. Wilder -título original: The Lost Weekend-, en la que Don Birnam (Ray Milland) aparece como un escritor fracasado a causa de su adicción a la bebida, dependencia que lo ha destruido física y moralmente hasta volverlo un sujeto abúlico. 
bulevar de las estribaciones y la repentina oscuridad fresca y el soplo del viento desde el mar.

Redactadas como una suerte de travelling, estas líneas que exponen lo que ve el ojo humano parecieran retener, en su sucesión enumerativa, destellos veloces de una realidad inmortalizada por una cámara filmadora, que, erigida sobre una plataforma móvil, se desplaza al compás de la mirada errática del detective, narrador autodiegético y subjetivo de la historia.

\section{Conclusiones}

Interpelar al cine como tema o como paradigma expresivo no conlleva la conversión de una novela o un cuento en película, pero sí determina la manera en que las obras analizadas deben leerse. Con la hegemonía de esta estrategia, que apuesta por encabalgar la ficción literaria con el arte cinematográfico, se asegura la inmersión del primer bloque en el segundo, todo ello realzado con descarado cinismo pero no entrevisto como un simple suplemento cultural y estilístico. En la obra chandleriana, lo que la palabra formula se toma a sí mismo como «auténtico»; pero esa autenticidad se encara a otros discursos de estatus fantasioso a partir de una ilusión intrínseca capaz de promover un desdoblamiento que se encamina a hacer que el relato, en cierto modo una crónica en primera persona que posibilita lecturas transversales de la despiadada sociedad del hurto y del crimen, de individuos sin moral y de las bandas de gánsteres y chantajistas que infectaban las capitales y las pequeñas ciudades de provincias americanas, abandone su esencia fictiva, o, en otras palabras, se «desficcionalice».

Pero ese proceso convencional de «desficcionalización» que apuntamos es engañoso al desencadenarse, paradójicamente, dentro de las coordenadas de la misma ficción, de tal suerte que, por mucho que novelistas y cuentistas se afanen en dignificar la narrativa policiaca, el género noir en sí no es ni pretende ser un documento histórico, ni un acta notarial, ni una gélida noticia de prensa estampada en las páginas de un periódico, aunque remita a conflictos previsiblemente reales o históricos. En contraposición a ello, aun cuando ofrezca falsos simulacros del mundo externo, su factura se recubre de un ambiguo y añejo linimento de naturalismo camp que le otorga esa impresión estilizada de vicio, de corrupción y maldad que empatiza con las emociones más abyectas del modélico lector norteamericano de los años 30 y 40, ese que hipócritamente disfrutaba con esos universos de crimen y delincuencia que se disputan el cine y la literatura, a la par que, de puertas afuera, se escandalizaba de la más mínima transgresión al orden. Por tal motivo, las instrucciones que acentúan, dentro del relato hard-boiled, un enunciado que se confronta a un hecho de signo cinematográfico imponen 
señales evidentes que problematizan la ambivalente realidad que se gesta a partir de fuerzas motrices metaficcionales que deconstruyen, mediante un relativo empeño por librar la ficción de sus mimbres reconocidamente artísticos, las virtudes del texto en cuanto artificio estético, dejando así a la intemperie los pespuntes estructurales que festonean la armazón novelesca, imaginativa y «cinemática» de este interesante corpus de obras.

Si, como nos recuerda Stam (2009: 7), «el cine es una forma de escritura que toma cosas prestadas de otras formas de escritura», la literatura, incluso la forjada por Chandler para el público de masas, hará otro tanto con el cine, singularmente con el cine hollywoodense, que es el modelo más inmediato. De él vampiriza sus técnicas, sus productos y su imaginario, pese a que $a$ priori abomine de todo ello. De este modo sus textos amplifican las claves miméticas $\mathrm{y}$, por lo tanto, ficticias que acreditan muchos de sus principios reguladores. Centro de imágenes icónicas, creador de deslumbrantes mitos y de articulaciones culturales, Hollywood alberga, aparte de una poderosa industria del entretenimiento, la sede de una Babilonia moderna que camina tambaleante hacia el desequilibrio psicopatológico; un territorio de ansiedades, de egoístas espejismos por el que anda suelta la violencia como un virus mortífero. En plena era poscapitalista, esta plaga deshumanizadora arrastra tanto a la élite que logra encaramarse hasta las colinas resplandecientes de Los Ángeles, donde presuntamente goza de una existencia confortable, como al resto de ejemplares subalternos que orbitan como satélites en torno a esa comunidad privilegiada; seres reducidos a la insignificancia, a la degradación, lastimeros receptáculos de pesadillas grotescas o juguetes rotos y desechables que, como insectos, caen en las garras de una sociedad espiritual y moralmente en bancarrota. La novela negra, con su amor por lo depravado, por la codicia y la ambición, no duda en adentrarse temáticamente en el oscuro subsuelo de la fama, en lo soez, más que en el vacuo glamur, pero, aunque se prescinda de argumentos localizados en el Hollywood más bizarro, al menos canibaliza en el plano escritural muchos de los motivos y engranajes que ha instituido el cine norteamericano en el que se han formado varias generaciones.

\section{BibliografíA}

Adler, T. (2008): Hollywood y la mafia. Los sangrientos gánsters de la historia y su influencia en el mundo del cine. Barcelona, Robinbook.

Arribas, V. (2010): El cine negro. Madrid, Notorious.

BARTUAL, R. (2007): «La novela policíaca: ficción detectivesca y 'hard-boiled'. El modelo norteamericano como transgresor de la norma inglesa». Despalabro, 1, págs. 97-107.

Bergman, A. (1983): Hollywood y LeVine. Barcelona, Bruguera. 
Bordwell, D. (1996): La narración en el cine de ficción. Barcelona, Paidós.

Chandler, R. (2010): Todos los cuentos. Barcelona, RBA.

- (2012): Todo Marlowe. Barcelona, RBA. 8. ${ }^{\mathrm{a}}$ ed.

- (2013): A mis mejores amigos no los he visto nunca. Cartas y ensayos selectos. Barcelona, Random House Mondadori.

Chatman, S. (2013): Historia y discurso. La estructura narrativa en la novela y en el cine. Barcelona, RBA.

Clark, A. (1996): Raymond Chandler in Hollywood. Los Angeles, Silman-James.

Eco, U. (1964): Apocalittici e integrati. Comunicazioni di massa e teorie della cultura di massa. Milano, Bompiani.

- (1996): «Detenerse en el bosque». En Seis paseos por los bosques narrativos. Barcelona, Lumen, págs. 57-82.

Eisenstein, S.M. (1995): «Dickens, Griffith y el cine en la actualidad». En Leyda, J. (ed.): La forma del cine. México, Siglo XXI, págs. 181-234 (3. ${ }^{a}$ ed.).

Gabler, N. (2015): Un imperio propio. Cómo los judíos inventaron Hollywood. [Aguadulce (Almería)], Confluencias.

Gaudreault, A. y Jost, F. (1995): El relato cinematográfico. Cine y narratología. Barcelona, Paidós.

González de la Aleja, M. (2006): «Novela hard-boiled: el límite de la frontera». En Martín Escrivà, Á. y Sánchez Zapatero, J. (eds.): Manuscrito criminal. Reflexiones sobre novela y cine negro. Salamanca, Librería Cervantes, págs. 55-68.

González-Cascos, E. (1998): La conversión gramatical de Raymond Chandler. Tesis Doctoral. Universidad de Valladolid.

Hamilton, C.S. (1987): Western and Hard-Boiled Detective Fiction in America. From High Noon to Midnight. Iowa City, University of Iowa.

Heredero, C.F. y Santamarina, A. (1996): El cine negro. Marginación y crisis de la escritura clásica. Barcelona, Paidós.

Irish, W. (2004): «Fue anoche». En No quisiera estar en sus zapatos. Madrid, El País, págs. 65-153.

Jost, F. (2002): El ojo-cámara. Entre el film y la novela. Buenos Aires, Catálogos.

Kaminsky, S. (1987): Disparen sobre Errol Flynn. Madrid, Júcar.

Lipovetsky, G. y Serroy, J. (2009): La pantalla global. Cultura mediática y cine en la era hipermoderna. Barcelona, Anagrama.

Luhr, W. (1991): Raymond Chandler and Film. Tallahassee, Florida State University. 2. ${ }^{\mathrm{a}} \mathrm{ed}$

MacDonald, R. (1983): La piscina mortal. Barcelona, Forum.

MacShane, F. (2017): La vida de Raymond Chandler. Barcelona, Alrevés.

Marcus, M. (1986): Italian Film in the Light of Neorealism. Princeton, Princeton University.

Moore, L.D. (2006): Cracking the Hard-Boiled Detective. A Critical History from the 1920 s to de Present. Jefferson, McFarland \& Company. 
Neira, M.R. (2003): Introducción al discurso narrativo fílmico. Madrid, Arco/Libros.

Pendo, S. (1976): Raymond Chandler on Screen. His Novels into Film. Scarecrow, Metuchen.

Pérez Bowie, J.A. (2008): Leer el cine. La teoría literaria en la teoría cinematográfica. Salamanca, Universidad de Salamanca.

Pérez Villarreal, L. (2001): Cine y literatura. Entre la realidad y la imaginación. Quito, Abya-Yala.

Phillips, G.D. (2000): Creatures of Darkness. Raymond Chandler, Detective Fiction, and Film Noir. Lexington, The University Press of Kentucky.

Plett, H.F. (1991): «Intertextualities». En Plett, H.F (ed.): Intertextuality. Berlin, Walter de Gruyter, págs. 3-29.

Plimpton, G. (ed.) (1976): Writers at Work. The 'Paris Review' Interviews. New York, Wiking.

Prada, J.M. de (2006): «Prólogo». En Aresté, J.M.: Escritores de cine. Relaciones de amor y odio entre doce autores y el celuloide. Madrid, Espasa Calpe, págs. 15-19.

Rhodes, C. (2008): Politics, Desire, and the Hollywood Novel. Iowa City, University of Iowa.

SÁnchez Navarro, J. (2006): Narrativa audiovisual. Barcelona, Uoc.

Sánchez Noriega, J.L. (2000): De la literatura al cine. Teoría y análisis de la adaptación. Barcelona, Paidós.

Seed, D. (2009): «John Dos Passos and the Art of Montage». En Cinematic Fictions. The Impact of the Cinema on the American Novel up to World War II. Liverpool, Liverpool University, págs. 128-150.

Segre, C. (1982): «Intertestuale-interdiscorsivo. Appunti per una fenomenología delle fonti». En Di Girolamo, G. y Paccagnella, I. (eds.): La parola ritrovata. Fonti $e$ analisi letteraria. Palermo, Sallerio, págs. 15-28.

- (1984): «Intertestualità e interdiscorsività nel romanzo e nella poesia». En Teatro e romanzo. Due tipi di comunicazione letteraria. Torino, Einaudi, págs. 103-118.

Sklovski, V. (1971): «Literatura y cine». En Cine y lenguaje. Barcelona, Anagrama, págs. 27-82.

Sмith, E.A. (2000): Hard-Boiled. Working-Class Readers and Pulp Magazines. Philadelphia, Temple University.

Stam, R. (2001): Teorías del cine. Una introducción. Barcelona, Paidós.

- (2009): Teoría y práctica de la adaptación. México, UnAm.

Todorov, T. (1971): «La typologie du roman policier». En Poétique de la prose. Paris, Seuil, págs. 55-65.

Vanoye, F. (2005): Récit écrit, récit filmique. Paris, Armand Colin.

VÁzquez Abejjón, S. (2017): «Influencia del cine de los orígenes en la literatura española del siglo xx». El Genio Maligno, 20, págs. 27-43 (en línea: <https://elgeniomaligno.eu> [consulta: 12 de febrero de 2019]).

Villanueva, D. (1994): Estructura y tiempo reducido en la novela. Barcelona, Anthropos. 